\title{
Distribution of Zinc in Selected Benchmark Soils of South Western Nigeria
}

\author{
E. Y. Thomas ${ }^{1}$, J. A. I. Omueti ${ }^{1} \&$ A. A. Adebisi ${ }^{1}$ \\ ${ }^{1}$ Department of Agronomy, University of Ibadan, Ibadan, Nigeria \\ Correspondence: E. Y. Thomas, Department of Agronomy, University of Ibadan, Ibadan, Nigeria. Tel: \\ 234-807-762-5414. E-mail: thomaseunice.eunice@gmail.com
}

Received: November 9, 2017

Accepted: December 17, 2017 Online Published: January 15, 2018

doi:10.5539/jas.v10n2p271

URL: https://doi.org/10.5539/jas.v10n2p271

\begin{abstract}
The Understanding of the different fractions of Zinc in soils is important to effectively manage fertilizer resources due to the low availability of Zinc in the native soil worldwide. Bioavailability, uptake of Zinc by plant and its fractions depend largely on the soil parent material, the type of chemical transformation the soil has been expose to over times and some anthropogenic intervention. This study examined five different $\mathrm{Zn}$ pools.

The distribution of $\mathrm{Zn}$ in soil fractions was determined for seven selected soils of South Western Nigeria. A sequential batch extraction which had been modified was used to identify $\mathrm{Zn}$ fractions and were separated into: the extractable zinc $(\mathrm{Ex}-\mathrm{Zn})$, zinc associated with the carbonate $\left(\mathrm{CO}_{3}-\mathrm{Zn}\right)$, the organically bound zinc $(\mathrm{Org}-\mathrm{Zn})$, sesquioxide (Ox-Zn) and residual (Res-Zn) in each soil. Total $\mathrm{Zn}$ was estimated as a sum of all the pools.

Result showed that Zinc fractions in the soils were in this order: extractible pool $(3.8 \%)<$ organic pool $(13.6 \%)$ $<$ carbonate pool $(14.8 \%)<$ sesquioxide pool $(22.8 \%)<$ residual pool $(45.1 \%)$. The residual pool amounts for almost half of the zinc that made up the total zinc in the soil. The distribution of zinc into these pools were determined by selected physical and chemical properties of the soil; the $\mathrm{pH}$, organic carbon, clay, $\mathrm{CEC}$, and phosphorus. However, soil phosphorus and $\mathrm{pH}$ had the highest influence on the zinc in the experimental soils. The stable fraction that dominated the soil was evident in the low extractable $\mathrm{Zn}$ fractions in the soil. Which is an indication of the inherently low levels of the bioavailability of $\mathrm{Zn}$ in the selected soils used in this study.
\end{abstract}

Keywords: zinc, bio-availability, batch extraction, sesquioxides, carbonate and residual

\section{Introductions}

Zinc, an essential micronutrient is used by plant, animal and humans for different reproductive and physiological functions (Chirma \& Yerokun, 2012). It affects plant growth, yield and quality (Madyiwa et al., 2002; Antoniads \& Alloway, 2003; Chidanandappa et al., 2008). Zinc is a co-factor in more than 300 enzymes and numerous transcription factors in human beings (FAO/WHO/IAEA, 1996; Haug et al., 2010; Chirma \& Yerokun, 2012). Lack of zinc in human diet could cause impaired growth in children and can results in poor human development (Hambridge et al., 1986). This incident is a common occurrence in African regions and needs urgent attention. Before now attention had been focused on heavy metal toxicities in humans exposed to mining operations and other source of pollution, neglecting its importance in crop production (Tembo et al., 2006). The followings symptoms: headaches, nausea, loss of appetite and diarrhea were recorded clinically from those exposed to high Zinc concentration (Panel on Micronutrients, 2001).

Uptake of zinc by plant is largely from the exchangeable fractions from the chemical transformation of its pools from the soil solution (Shuman, 1991). Another source of zinc for plant uptake is from organic and anthropogenic atmospheric input (Iyengar et al., 1981; Johnson \& Petras, 1998). Total zinc in soil ranged from $10-330 \mathrm{mg} / \mathrm{kg}$ and had a mean value of $55 \mathrm{mg} / \mathrm{kg}$ (Kiekens, 1995), this does not give a holistic view about its availability and transformation in soils. In order to have a broad understanding of total zinc in soil, sequential or batch fractions analytical methods have been used to describe five functional fractions that quantified it in soils (Zerbe et al., 1999; Hseu, 2006; Fedotov \& Spivakov, 2008; Saffari et al., 2009). These includes: water soluble fractions (found in soil solution), exchangeable Zinc, which is occur with a non-specific reaction with the soil particles, zinc adsorbed to soil organic ligands or organic $\mathrm{Zn}$ complexed, $\mathrm{Zn}$ fractions that is inorganically associated with secondary minerals like carbonates or insoluble metal oxides and the last is the residual form of 
zinc which is found associated with primary minerals (Sposito et al., 1982; Antoniads \& Alloway, 2003; Saffari et al., 2009). This information gave a wide information about the chemical, biological and geological processes in soil which is a tool that can be employed to predict $\mathrm{Zn}$ availability for plant uptake. Some of these factors: $\mathrm{pH}$, Cation exchange capacity (CEC) the presence of metal oxides and soil organic matter affect the extents to which the fractions of $\mathrm{Zn}$ present in soil is transformed when equilibrium is reached. Reports by scientists had it that the residual $\mathrm{Zn}$ and zinc bound to the oxides formed the most stable fractions though not available for plant uptake while the exchangeable and water soluble forms are more soluble and available (Saffari et al., 2009).

The low solubilization of zinc from soil minerals coupled with low native $\mathrm{Zn}$ and its strong adsorption on soil surfaces or co-leaching of zinc with dissolved organic matter had given rise to low concentration of bio-available Zn in most soils (Zimdahl \& Skogerboe, 1977; Rieuwerts et al., 2006). This incidence had also resulted into a widespread of $Z n$ deficiency in several regions of the world including the savannah in Nigeria (Agbeni, 2003), Australia (McDonald et al., 2001), Spain (Obrador et al., 2007), India (Karak et al., 2006), Brazil (Furlani et al., 2005), Turkey (Cakmak et al., 1999) and Iran (Maftoun \& Karimian, 1989). The increase in zinc deficiency reported in developing countries had been a major contributor to increased incidence in childbirth, poor growth, reduction in infectious disease resistance and impaired cognitive development (FAO, 1997). About 800,000 people die annually due to zinc deficiency according to WHO report and out of these number 450,000 are children under age five (Das \& Green,2013). Zinc riches sources are from flesh food but Africa derived their own zinc majorly from whole-grain staple food which only provide low zinc and eventually lead to zinc deficiency. More importantly these staple food contain high phytate which further inhibit zinc absorption from the human gut. The objective of this study therefore was to define and characterize the different zinc forms in selected South Western Nigeria soils and also determine their distribution as affected by the soil chemical and physical properties.

\section{Materials and Methods}

\subsection{Soils}

The experimental soils were collected from seven locations in South Western Nigeria (Table 1). Samples were obtained from two different depth: 0-15 and $15-30 \mathrm{~cm}$ at ten random spots per field and mixed together to obtain one composite sample. All samples were air dried and crushed to pass through $2 \mathrm{~mm}$ sieve.

\subsection{Laboratory Analysis}

Soil samples were air-dried, crushed gently with pestle and mortar and sieved using $2 \mathrm{~mm}$ sieve to remove soil particles greater than $2 \mathrm{~mm}$. The soil samples were subjected to routine analyses. The $\mathrm{pH}$, total exchangeable acidity, exchangeable bases, total nitrogen, organic carbon content, available phosphorus and soil particle size distribution by methods largely described by Udo (1986).

\subsection{Zinc Fractionation}

A modified version of the batch or single extraction scheme (Johnson \& Petras, 1998) was used to characterize the various $\mathrm{Zn}$ fractions in the soils. Instead of using the same soil residue in the next extraction step, fresh samples were weighed into the next reagent as follows (Chirma \& Yerokun, 2012):

(a) Extractible $\mathrm{Zn}(\mathrm{Ex}-\mathrm{Zn})$ : Which represent the water soluble and exchangeable fraction: twenty grams of soil was extracted in 0.1 N HCL (Wear \& Summer, 1948).

(b) Carbonate bound $\mathrm{Zn}$ or the inorganically bound $\mathrm{Zn}\left(\mathrm{CO}_{3}-\mathrm{Zn}\right)$ : one gram of soil was extracted in $20 \mathrm{ml} 1 \mathrm{M}$ $\mathrm{CH}_{3} \mathrm{COONH}_{4} / \mathrm{CH}_{3} \mathrm{COOH}$ mixture at $\mathrm{pH} 5$ for 5 hours.

(c) Organic bound $\mathrm{Zn}(\mathrm{Org}-\mathrm{Zn})$ : which represent the fraction complexed, chelated or adsorbed: one gram of soil was extracted in $40 \mathrm{ml} 0.1 \mathrm{M} \mathrm{K}_{2} \mathrm{P}_{2} \mathrm{O}_{7}$ for 17 hours and then filtered.

(d) Sesquioxide $\mathrm{Zn}(\mathrm{Ox}-\mathrm{Zn})$ : representing the amorphous bound fraction: one gram of soil was extracted in $50 \mathrm{ml}$ acid oxalate (four parts $0.2 \mathrm{M}$ ammonium oxalate and three parts $0.23 \mathrm{M}$ oxalic acid). The $\mathrm{pH}$ was adjusted to 3 using either of the two reagents used in preparing of acid oxalate. The sample mixture was shaken for 17 hours.

(e) Residual $\mathrm{Zn}$ (Res-Zn): This was determined after digesting one gram soil sample in $25 \mathrm{ml}$ aqua regia (one part $\mathrm{HNO}_{3}$ to three parts $\mathrm{HCL}$ ) for twenty minutes on a hot plate and then allowed to cool

(f) Total $\mathrm{Zn}$ (Tot-Zn): Total $\mathrm{Zn}$ was calculated as a sum of all the fractions determined.

Soil suspensions from each fractions above were filtered after shaking vigorously. The fractions of Zinc in each fractions were determined by the atomic absorption spectrophotometer (AAS). 


\subsection{Statistical Analysis of the Data}

Statistical analysis of data was done using the SAS Statistical Package to estimate the means, standard deviations, maximum and minimum zinc concentration in different pools. Simple correlation coefficients were used to show the relationship between the physical properties of the soil and the fractions of $\mathrm{Zn}$. Correlation coefficient determines how best the physical properties of the soil affect the different fractions of $\mathrm{Zn}$.

Table 1. Characterization, Classification and location of experimental soil

\begin{tabular}{llll}
\hline Soil series & Location & Parent rock/material & Classification \\
\hline Alagba & Ogun state & Medium-grained granite/gneiss & Ultisol \\
Apomu & IAR\&T Campus(Ibadan) & Medium-grained granite/gneiss & inceptisol \\
Eruwa & Eruwa, Oyo State & Coarse-granites and gneisses & Alfisol \\
Ibadan & IAR\&T Campus(Ibadan) & Coarse-granites and gneisses & Alfisol \\
Matako & IAR\&T Campus(Ibadan) & Alluvial/colluvial & Inceptisol \\
\hline
\end{tabular}

\section{Results}

\subsection{Properties of Soils from Selected Areas in South West Nigeria}

The $\mathrm{pH}\left(\mathrm{H}_{2} \mathrm{O}\right)$ of the soils ranged from 5.0 to 6.99 (Table 2). It was observed that 21 percent of the ten soils analyzed were strongly acidic; 21 percent moderately acidic; 36 percent slightly acidic and 22 percent were neutral. Of these, the following Alagba series (top and subsoil), Apomu (top soil) and Matako were observed to be strongly acidic. While for the other series $\mathrm{pH}$ was slightly acid and close to neutral. Soil Nitrogen concentration in the soils ranged from 0.02 to $0.25 \mathrm{~g} / \mathrm{kg}$, Eruwa (top soil)-Ibadan (subsoil), this shows that nitrogen concentration in these soils is very low. Organic carbon ranged from 0.88 in Alagba series topsoil to 6.46 at the subsoil in Alagba series. Generally, the organic carbon of the soil was low. Phosphorus value in the soil ranged from 2.80 to $80 \mathrm{mg} / \mathrm{kg}$, which is low. Potassium also ranged from $0.04-0.16 \mathrm{cmol} / \mathrm{kg}$, also Magnesium ranged from 0.6 to $2.22 \mathrm{cmol} / \mathrm{kg}$ all in Eruwa soil. Sodium value in the experimental soil ranged from 0.15 in both Alagba and Apomu top soil to $0.23 \mathrm{cmol} / \mathrm{kg}$ in Eruwa subsoil. Exchangeable soil acidity ranged from $0.40-0.80 \mathrm{cmol} / \mathrm{kg}$ in Ibadan soil.

The manganese levels of soils ranged from (31.1-512.2 $\mathrm{mg} \mathrm{kg}^{-1}$ ), which is low. Copper concentration in these soils ranged from 1.40 in Eruwa top soil to $6.60 \mathrm{mg} / \mathrm{kg}$ in Ibadan subsoil. The Iron level of the soil ranged from (66.1-964.5 $\mathrm{mg} \mathrm{kg}^{-1}$ ) (Table 2).

The highest $0.1 \mathrm{~N} \mathrm{HCl}$ extractable zinc was observed in the Ibadan series $\left(14.2 \mathrm{mg} \mathrm{kg}^{-1}\right)$ followed by Apomu series $\left(6 \mathrm{mg} \mathrm{kg}^{-1}\right)$. It was observed that 64 percent of the soils analyzed were below the critical limits (Table 4). The ECEC was generally low for all the soils analyzed but one; Apomu series $(13.65 \mathrm{cmol} / \mathrm{kg})$. Analysis of the soil showed that 22 percent were sandy loam, while $78 \%$ were loamy sand (Table 3 ). The coarse textured soils had the lowest extractible and total zinc. The extractible zinc of these soils was low: Eruwa series $(0.4 \mathrm{mg} / \mathrm{kg})$ and Matako series $(1.0 \mathrm{mg} / \mathrm{kg})$. The sandy loam soils with their corresponding moderate organic matter had the highest extractible zinc: Ibadan series $(14.2 \mathrm{mg} / \mathrm{kg})$ and Apomu series $(6.0 \mathrm{mg} / \mathrm{kg})$. The total zinc of the sandy loam soils was high: Apomu series $(68.75 \mathrm{mg} / \mathrm{kg})$ and Ibadan series $(211.6 \mathrm{mg} / \mathrm{kg})$.

\subsection{Characterization of Zinc in Its Various Fractions in the Soils}

The batch fractionation scheme was used to define the following five different pools of $\mathrm{Zn}$ from the 10 soils analyzed: the exchangeable pool (F1), carbonate bound Zn (F2), organic Zn pool (F3), sesquoxide bound Zn (F4), residual $\mathrm{Zn}$ pool (F5). The zinc pools were in the order: exchangeable zinc $(3.8 \%)<$ organic zinc $(13.6 \%)<$ carbonate bound zinc $(14.8 \%)<$ sesquioxide zinc $(22.8 \%)<$ residual zinc $(45.1 \%)$.

The extractable zinc was the lowest pool in all the series and it was observed to be $3.8 \%$ (Table 4). 
Table 2. Chemical properties of experimental soils

\begin{tabular}{|c|c|c|c|c|c|c|c|c|c|c|c|c|c|}
\hline Series & $\mathrm{pH}_{\left(\mathrm{H}_{2} \mathrm{O}\right)}$ & $\mathrm{N}$ & $\mathrm{OC}$ & $\mathrm{P}$ & $\mathrm{K}$ & $\mathrm{Ca}$ & $\mathrm{Mg}$ & $\mathrm{Na}$ & EA & ECEC & $\mathrm{Mn}$ & $\mathrm{Cu}$ & $\mathrm{Fe}$ \\
\hline & & \multicolumn{2}{|c|}{----- g/kg ---- } & $-\mathrm{mg} / \mathrm{kg}-$ & \multicolumn{6}{|c|}{ 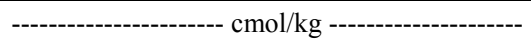 } & \multicolumn{3}{|c|}{--------- mg/kg --------- } \\
\hline Apomu $(0-15 \mathrm{~cm})$ & 5.3 & 0.03 & 6.22 & 2.80 & 0.05 & 0.91 & 1.03 & 0.15 & 0.70 & 2.84 & 95.30 & 4.60 & 143.30 \\
\hline Apomu $(15-30 \mathrm{~cm})$ & 6.3 & 0.03 & 4.23 & 17.10 & 0.05 & 1.33 & 11.40 & 0.17 & 0.70 & 13.65 & 84.50 & 4.10 & 513.20 \\
\hline Alagba $(0-15 \mathrm{~cm})$ & 5.7 & 0.03 & 0.88 & 8.40 & 0.04 & 1.21 & 1.07 & 0.15 & 0.50 & 2.97 & 51.10 & 3.30 & 445.10 \\
\hline Alagba $(15-30 \mathrm{~cm})$ & 5.2 & 0.09 & 5.35 & 5.20 & 0.09 & 1.34 & 1.61 & 0.19 & 0.60 & 3.83 & 94.30 & 3.20 & 193.30 \\
\hline Matako $(0-15 \mathrm{~cm})$ & 5.0 & 0.18 & 5.43 & 1.20 & 0.06 & 1.06 & 1.56 & 0.15 & 0.50 & 3.33 & 91.30 & 3.40 & 175.60 \\
\hline Matako $(15-3 \mathrm{~cm})$ & 6.2 & 0.21 & 3.11 & 2.80 & 0.04 & 1.35 & 1.75 & 0.19 & 0.60 & 3.93 & 64.50 & 3.40 & 706.30 \\
\hline Ibadan $(0-15 \mathrm{~cm})$ & 6.4 & 0.03 & 1.28 & 2.80 & 0.04 & 1.50 & 1.61 & 0.19 & 0.40 & 3.74 & 81.20 & 2.80 & 964.50 \\
\hline Ibadan $(15-30 \mathrm{~cm})$ & 6.1 & 0.25 & 6.46 & 80.00 & 0.14 & 1.52 & 1.73 & 0.20 & 0.80 & 4.39 & 202.10 & 6.60 & 842.80 \\
\hline Eruwa $(0-15 \mathrm{~cm})$ & 6.6 & 0.05 & 2.16 & 5.70 & 0.06 & 1.24 & 0.60 & 0.15 & 0.60 & 2.65 & 31.10 & 1.60 & 91.40 \\
\hline Eruwa $(15-30 \mathrm{~cm})$ & 6.0 & 0.02 & 3.51 & 9.60 & 0.16 & 1.35 & 2.22 & 0.23 & 0.70 & 4.66 & 55.60 & 1.40 & 87.60 \\
\hline
\end{tabular}

Table 3. Physical properties of the soils collected from different locations

\begin{tabular}{lllll}
\hline Soil & Sand & Silt & Clay & Textural class \\
\hline & -------- & \\
Apomu $(0-15 \mathrm{~cm})$ & 780 & 164 & 56 & Sandy loam \\
Apomu $(15-30 \mathrm{~cm})$ & 760 & 164 & 76 & Sandy loam \\
Alagba $(0-15 \mathrm{~cm})$ & 820 & 56 & 124 & Loamy sand \\
Alagba $(15-30 \mathrm{~cm})$ & 760 & 164 & 76 & Sandy loam \\
Matako $(0-15 \mathrm{~cm})$ & 800 & 144 & 56 & Loamy sand \\
Matako $(15-3 \mathrm{~cm})$ & 740 & 164 & 96 & Loamy sand \\
Ibadan $(0-15 \mathrm{~cm})$ & 780 & 144 & 76 & Sandy loam \\
Ibadan $(15-30 \mathrm{~cm})$ & 780 & 124 & 96 & Sandy loam \\
Eruwa $(0-15 \mathrm{~cm})$ & 720 & 156 & 124 & Loamy sand \\
Eruwa $(15-30 \mathrm{~cm})$ & 720 & 164 & 116 & Loamy sand \\
\hline
\end{tabular}

Table 4. Soil Zinc $(\mathrm{mg} / \mathrm{kg})$ in its various fractions in the soils

\begin{tabular}{llllllll}
\hline S/N & Soil & ex-Zn & org-Zn & co-Zn & seq-Zn & res-Zn & Total \\
\hline 1 & Apomu (0-15) & 6.00 & 16.80 & 20.20 & 3.50 & 22.25 & 68.75 \\
2 & Apomu (15-30) & 2.80 & 10.70 & 15.30 & 6.00 & 19.50 & 54.3 \\
3 & Alagba (0-15) & 1.60 & 9.00 & 11.10 & 13.50 & 21.25 & 56.45 \\
4 & Alagba (15-30) & 3.00 & 8.50 & 9.20 & 16.50 & 21.50 & 58.7 \\
5 & Matako (0-15) & 1.00 & 4.80 & 3.20 & 6.00 & 11.50 & 26.5 \\
6 & Matako (15-30) & 1.00 & 8.70 & 20.70 & 52.00 & 27.50 & 109.9 \\
7 & Ibadan (0-15) & 14.20 & 8.50 & 10.40 & 14.50 & 164.00 & 211.6 \\
8 & Ibadan (15-30) & 7.50 & 50.20 & 23.50 & 9.00 & 110.50 & 200.7 \\
9 & Eruwa (0-15) & 0.40 & 2.60 & 2.20 & 5.50 & 8.00 & 18.7 \\
10 & Eruwa (15-30) & 0.80 & 2.00 & 11.00 & 13.50 & 8.75 & 36.05 \\
Mean & & 3.83 & 12.18 & 12.68 & 14 & 41.48 & 96.06 \\
Std. D & & 4.34 & 14.02 & 7.20 & 14.09 & 52.41 & 62.24 \\
Minimum & & 0.4 & 2 & 2.2 & 3.5 & 8 & 16.10 \\
Maximum & & 14.2 & 50.2 & 23.5 & 52 & 164 & 303.9 \\
\hline
\end{tabular}

\subsection{Correlation Coefficients between Soil Zinc and Some Soil Properties}

Phosphorus and pH showed a positive correlation with exchange fractions of Zinc. Organic carbon, ECEC and Clay however showed a negative correlation with Exchangeable zinc fractions.

Organic zinc was highly correlated $(0.933)$ to the soil $\mathrm{P}$ and positively correlated to organic carbon, $\mathrm{pH}$ and ECEC of the soil. Correlation analysis showed that the carbonate bound zinc was positively correlated (0.537) 
with the soil phosphorus. It was also positively correlated $(0.382)$ with organic carbon but negatively correlated with clay. Soil $\mathrm{pH}$ and clay were positively correlated with sesquioxide bound zinc and negatively correlated with the soil organic carbon, ECEC and P.

The residual $\mathrm{Zn}$ pool showed a positively correlation with the soil Phosphorus and $\mathrm{pH}$. While a negative correlation existed between the following soil properties: ECEC, OC and clay. The total zinc concentration of the soils was positively correlated with the $\mathrm{pH}$ and Phosphorus but negatively correlated with ECEC, Organic carbon and clay (Table 5).

Table 5. Correlation coefficients between soil zinc fractions and some selected soils properties

\begin{tabular}{llllll}
\hline Zinc fraction & $\mathrm{pH}$ & $\mathrm{P}$ & ECEC & OC & Clay \\
\hline Exchangeable & 0.019 & 0.245 & -0.052 & -0.032 & -0.361 \\
Organic & 0.050 & $0.933^{* *}$ & 0.028 & 0.527 & -0.084 \\
Carbonate & 0.105 & 0.537 & 0.201 & 0.382 & -0.138 \\
Sesquioxide & 0.190 & -0.170 & -0.129 & -0.248 & 0.177 \\
Residual & 0.353 & 0.408 & -0.082 & -0.135 & -0.148 \\
Total & 0.340 & 0.536 & 0.065 & 0.008 & -0.131 \\
\hline
\end{tabular}

Note. ${ }^{*}=$ significant at 0.05 (2-tailed); $\mathrm{P}=$ phosphorus; $\mathrm{EC}=$ exchangeable cation; $\mathrm{OC}=$ organic carbon.

\section{Discussion}

The $\mathrm{pH}$ of the soils were acidic and some were close to neutral. Solubility of metals increases at lower $\mathrm{pH}$ thereby enhancing adsorption reactions rather than precipitation and complexation reactions. Even though adsorption tends to decreases with lowering $\mathrm{pH}$ because of the competition of protons with potential toxic metal cations for adsorption sites on soil colloids. Thereby making the adsorption of $\mathrm{Zn}$ to be significant at $\mathrm{pH}$ of 5-6.5 (Rieuwertset et al., 1998). These $\mathrm{pH}$ are the ranges observed in this study. Adeoye (1986) observed that acidic soils were prone to aluminium and manganese toxicity and this causes reduction in crop productivity. Johnson and Petras (1998) made similar observations and concluded that at a low pH the solubility of most nutrients increase causing toxicity problems for many crops. At high $\mathrm{pH}$ or if the soil is over limed, has low organic matter and is light to medium textured, the nutrient status is generally poor because the solubility of most micronutrients reduces (Modaihsh, 1997).

The manganese levels of soils were low when compared to the one reported by Sparks (1995), that small amounts of manganese in soils ranging from 20 to $10,000 \mathrm{mg} \mathrm{kg}^{-1}$, whereas Adriano (2001) reported the total manganese contents ranged between $450-4,000 \mathrm{mg} \mathrm{kg}^{-1}$. Iron $(\mathrm{Fe})$ level in the soil range was low when compared to the critical level of iron in the soil reported by Deb and Sakal (2002) is $2.5-5.8 \mathrm{mg} \mathrm{kg}^{-1}$. The highest $0.1 \mathrm{~N} \mathrm{HCl}$ extractable zinc observed in the Ibadan series followed by Apomu series were also below the critical level of zinc $\left(0.9 \mathrm{mg} \mathrm{kg}^{-1}\right)$ in soils observed by Esu (1991). About 64 percent of the soils analyzed were below the critical limits as shown in (Table 4).

Mapiki and Phiri (1995) reported low ECEC ranged from 6 to $13 \mathrm{cmol} / \mathrm{kg}$ while high ECEC ranged from 12 to $20 \mathrm{cmol} / \mathrm{kg}$. From this background, the ECEC was generally low for all the soils analyzed but one; Apomu series $(13.65 \mathrm{cmol} / \mathrm{kg})$. Soil Nitrogen concentration in the soils ranged from $(0.02$ to $0.25 \mathrm{~g} / \mathrm{kg})$, this shows that the $\mathrm{N}$ is very low. The critical range of $\mathrm{N}$ in soils is reported as $1.1-2 \mathrm{~g} / \mathrm{kg}$ by FFD (2012). The lowest phosphorus value observed was below the critical level of $7-20 \mathrm{mg} / \mathrm{kg}$ P reported by FFD (2012). The organic carbon too was below the critical range of $4-10 \mathrm{mg} / \mathrm{kg}$ reported by FFD (2012) which is $4-10 \mathrm{mg} / \mathrm{kg}$.

The coarse textured soils in this study had the lowest extractable and total zinc, probably because of their poor ability to adsorb nutrients (Brady, 1984). The low ability of the loamy sand to adsorb nutrient could be because of the high sand content (which was above 74 percent) with their corresponding low organic carbon (Donahue et al., 1983). The lower Zn concentration in Matako and Eruwa series could be as a result of the lower $\mathrm{pH}$ which may induce the adsorption of Zinc. Matako series soils actually had the lowest possibly $\mathrm{pH}$ in this study. Availability of zinc had been reported by Alloway (1995) to decrease as the $\mathrm{pH}$ of the soil increases because of the lower solubility of $\mathrm{Zn}$ minerals and increasing adsorption of $\mathrm{Zn}$ by negatively charged colloidal soil properties. The sandy loam soils with their corresponding moderate organic matter had the highest extractable zinc, this may as a result of the fact that adsorption of zinc is favoured by organic matter in the soils and important in the formation of the organic zinc complexes that act as buffer zones for zinc (Udom et al., 2003). 
The distribution pattern of $\mathrm{Zn}$ observed in various soil fractions were similar to that reported by Behera et al. (2008) that the highest zinc concentration was observed in the residual pool. This could be attributed to residence time which takes place over the years and thereby reducing metal mobility and availability as a result of the following reactions: complexation, adsorption and precipitation of metal ions on soil particle surfaces according to Zauyah et al. (2004). Tehrain (2005) made same assertions that the relative abundance of zinc was more in the residual pool about $89 \%$ of the total zinc in Serbia. In addition to this explanation, Lu et al. (2004) also concluded in their findings that the fractionation of heavy metals in soil considering the effect of time revealed that soluble metals transformed from easily extractable fractions to more stable fractions. In fact both the residual and the oxide bound $\mathrm{Zn}$ fractions had been considered the stable fractions while the exchangeable and water soluble fraction were referred to as the more soluble fractions that were immediately available to plant (Saffari et al., 2009).

The lowest extractable zinc observed in all the soil was due to adsorption of zinc in soil as a result of the lower soil pH. Similarly, Ramzan et al. (2014) also reported the least $\mathrm{Zn}$ concentration in the water soluble fraction. This was also in agreement with Dvorak et al. (2003); that metal fractions associated with the exchangeable pool was the lowest in soils from Czech Republic. He defined the following pools: exchangeable ( 5 percent); Fe-Mn oxide ( 9 percent); organic (44 percent). Margui et al. (2007) and Elsokkary (1979) also made similar observations and reported that exchangeable pool was below detection (trace amount) in some of the samples analyzed. This low fraction associated with the exchangeable fraction could be due to losses from leaching and plant uptake, as these pools represents the fractions that are bioavailable and mobiles in soil (Filgueiras et al., 2002).

The positive correlation of total zinc with $\mathrm{pH}$ is an indication of zinc availability though in small concentration. Other factors apart from adsorption may be responsible for this result. The soil conditions that commonly lead to zinc deficiency in crops are low total zinc concentrations, such as sandy soils; highly weathered parent materials with low total zinc contents, such as tropical soils; high calcium carbonate contents, such as calcareous soils; neutral or alkaline $\mathrm{pH}$, as in heavily limed soils or calcareous soils; high salt concentrations, i.e., saline soils; peat and muck, as inorganic soils; and high phosphate status; prolonged waterlogging or flooding, as in rice soils; and high magnesium and/or bicarbonate concentrations in soils or irrigation water (Das \& Green, 2013, Alloway, 2008).

The correlation coefficient between phosphorus and the exchangeable zinc showed a highly positive relationship. Though low, the correlation between the exchangeable pool with the ECEC and organic carbon of the soils was positive. Organic zinc was highly correlated to the soil P. this means that the higher the concentration of $\mathrm{P}$, the higher the organic pool in the total zinc of the soil. Though low, the organic zinc was also positively correlated to the CEC, pH and organic carbon. This agrees with the study by Elsokkary (1979) in Egypt who showed that zinc adsorption is highly associated with ECEC and $\mathrm{Fe}_{2} \mathrm{O}_{3}$. Udom et al. (2004) also observed that the correlation between organic carbon and zinc was significant. Correlation analysis showed that the carbonate bound zinc was positively correlated (0.414) with the ECEC of the soil. It was also positively correlated (0.335) with the P which is an indication that there was a dynamic relationship between the zinc in the soil and the ECEC and $\mathrm{P}$ of these soils. Since the $\mathrm{pH}$ of the soils in the study area are acidic to near neutral one will expect little or no adsorption to carbonate. That is why the correlation of Zinc carbonate to organic carbon and clay is negative. This was corroborated by Joshi et al. (2014) that because the soil investigated was acidic between 4.57-6.83, no Carbonates will be expected. Also the correlation of carbonates to the Zinc form complexes such as $\mathrm{CaCO}_{3}: \mathrm{ZnCO}_{3}$, a double salt, with calcium carbonate (Ramos et al., 1999). He also noted that calcium carbonate tends to adsorb the $\mathrm{Zn}$ under favourably high $\mathrm{pH}$ values. There was a positive relationship between $\mathrm{pH}$ and carbon bound $\mathrm{Zn}$.

The sesquioxide bound zinc was positively correlated with the soil $\mathrm{pH}$, this means that as the soil $\mathrm{pH}$ decreases the sesquioxide zinc pool decreases. When the $\mathrm{pH}$ of a soil is low, the exchangeable pool increases therefore, reducing the stable fraction (sesquioxide and residual pools) of the zinc. The sesquioxide $\mathrm{Zn}$ pool is negatively correlated with the soil organic carbon. (Shiowatana et al., 2001; Leleyter \& Baraud, 2006) observed in their researches that reducible and oxidizable pools were not sensitive to $\mathrm{pH}$ changes but were highly affected by redox conditions and microorganism activity.

The residual Zn pool is highly positively correlated with the P. This means that the level of significance is high. As the soil P increases, the residual pool of the total zinc also increases. This could be explained by the fact that high soil P results in what is known as phosphorus induced zinc. The zinc would be held in the primary minerals making it unavailable for uptake. 
Because of the heterogeneous nature of the soils, results reported by other researchers could be very different. It was observed that only sesquioxide $\mathrm{Zn}$ pool of the soils analyzed was significantly correlated with clay (Table 5). However, many researchers have reported a significant correlation between clay and zinc fractions (Johnson \& Petras, 1998; Sinha et al., 1978). This means that the higher the amount of clay in a particular soil the higher the amount of zinc adsorbed.

\section{Summary and Conclusion}

The distribution of zinc was characterized into five different fractions: the exchangeable pool (3.8\%); organic pool (13.6\%); carbonate pool (14.8\%); sesquioxide pool (22.8\%) and the residual pool $(45.1 \%)$. The residual bound zinc was observed to be the largest fraction.

The zinc fractions can be demarcated into stable fractions that was made up of the oxidizable and residual Zinc then the intermediate which are majorly the fractions associated with the carbonates and the organically bound $\mathrm{Zn}$ while the exchangeable fraction is the available one which the plant take up through the root for its growth and development. Extractable $\mathrm{Zn}$ concentrations of these soils are generally low because the stable fraction is the dominant form in soils. The low concentration of Zinc in the exchangeable form (available) in the experimental soils is a confirmation of the slow release of these elements into soil solutions. Though the other fractions most especially the intermediate could be released to replenishing the exchangeable when equilibrium is attained. Zinc fractions however correlated with soil properties like, pH, ECEC, Clay, available P, and Organic carbon.

\section{References}

Adeoye, G. O. (1986). Comparative studies in ammonium bifluoride chelate extractants and some conventional extractants for sedimentary soils of South Western Nigeria (PhD thesis, University of Ibadan, Nigeria).

Adriano, D. C. (2001). Trace Elements in Terrestrial Environments: Biochemistry, Bioavailability and Risks of Metals (2nd ed., p. 879). Springer-Verlag, New York. https://doi.org/10.1007/978-0-387-21510-5

Agbenin, O. J. (2003). Zinc fractions and solubility in a tropical semi-arid soil under long term cultivation. Journal of Biology and Fertility of Soils, 37, 83-89.

Alloway B. J. (2008). Zinc in soils and crop nutrition. Paris, France: IFA; Brussels, Belgium: IZA.

Antoniadis, V., \& Alloway, B. J. (2003). Influence of time on the plant availability of $\mathrm{Cd}, \mathrm{Ni}$, and $\mathrm{Zn}$ after sewage sludge has been applied to soils. Agrochimica, 47, 81-93.

Behera, S. K., Singh, D., Dwivedi, B. S., Singh, S., Kumar, K., \& Rana, D. S. (2008). Distribution of fractions of zinc and their contribution towards availability and plant uptake of zinc under long-term maize (Zea mays L.)-wheat (Triticum aestivumL.) cropping on an Inceptisol. Australian Journal of Soil Research, 46, 83-89. https://doi.org/10.1071/SR07073

Brady, C. N. (1984). The Nature and Properties of Soils (9th ed., p. 78). Macmillian Publishing Company, New York.

Cakmak, I., Kalayci, M., Ekiz, H., Braun, H. J., Kilinct, Y., \& Yilmaz, A. (1991). Zinc deficieny as practical problem in plant and human nutrition in turkey: A NATO Science for Stability Project. Journal of Field Crops Research, 60(1-2), 175-188. https://doi.org/10.1016/S0378-4290(98)00139-7

Cakmak, I., Tolay, I., Ozdemir, A., Ozkan, H., Ozturk, L., \& Kling, C. I. (1999). Zinc Efficiency of Diploid, Tetraploid and Hexaploid Wheats. Annals of Botany, 84, 163-171. https://doi.org/10.1006/anbo.1999.0902

Chidanandappa, H. M., Khan, H., Chikkaramappa, T., \& Shivaprakash, B. L. (2008). Forms and distribution of zinc in soils under mulberry (Morus indica L.) of multivoltine seed area in Karnataka. Journal of Agricultural Science, 42, 26-32.

Chirma, M., \& Yerokun, O. A. (2012). The distribution of Zinc Fractions in surface samples of selected Agricultural Soils of Zambia. International Journal of Soil Science, 7(2), 51-60. https://doi.org/10.3923/ ijss.2012.51.60

Das, S., \& Green, A. (2013). Importance of zinc in crops and human health. Journal of SAT Agricultural Research, 11, 1-7.

Deb, D. L., \& Sakal, R. (2002). Micronutrients. Fundamentals of Soil Science (pp. 391-403). Indian Society of Soil Science; Indian Research Institute, New Delhi. 
Donahue, R. L., Miller, W., \& Shickluna, C. J. (1983). An introduction to soil and plant growth (5th ed., p. 187). Prentice-Hall: Englewood Cliffs, New Jersey.

Dvorak, P., Mtlutos, P., Szakova, J., Cerny, J., \& Balik, J. (2003). Distribution of soil fractions of zinc and its uptake by potatoes wheat and barley after soil amendment by sludge and inorganic zinc salt. Plant Soil Environment, 49, 203-212.

Elsokkary, H. I. (1979). The chemical fractionation of soil zinc and its specific and total adsorption by Egyptian alluvial soils. Plant and Soil, 53, 117-129. https://doi.org/10.1007/BF02181886

Esu, I. E. (1991). Derailed soil survey of NIHORT farm at Bunkure Kano State, Nigeria (p. 72). Institute. Agric. Res., Zaria.

FAO. (1997). Agriculture book and nutrition for Africa-A resource book for teacher of Agriculture. Food, nutrients and diets (Chapter 7). Retrieved December, 2017, from http:/www.fao.org/docrep/w0078e/ w0078e08.htm\#TopOfPage

FAO/WHO/IAEA. (1996). Trace Elements in Human Nutrition and Health (Vol. 15, pp. 86-87).. WHO, Geneva.

Fedotov, P. S., \& Spivakov, Y. B. (2008). Fractionation of elements in soils, sludges and sediments: batch and dynamic methods. Russian Chemical Review, 77(7), 649-660. https://doi.org/10.1070/RC2008v077n07 ABEH003791

FFD (Federal Fertilizer Department). (2012). Federal Ministry of Agriculture and Rural Development (Vol. 15, No. 2, pp. 1049-1058). Abuja, Nigeria.

Filgueiras, A. V., Lavilla, I., \& Bendicho, C. (2002). Chemical sequential extraction in environmental solid samples. J. Environ. Monit., 4, 823-857. https://doi.org/10.1039/b207574c

Furlani, N., Cangianifurlani, M., Robertomeda, P., Rotterduarte, A., \& Pereira, A. (2005). Efficiency of maize cultivars for zinc uptake and use. Scientia Agricola, 62(3), 264-273. https://doi.org/10.1590/S0103-9016 2005000300010

Hambridge, K. M., Casey, C. E., \& Krebs, N. F. (1986). Zinc. In W. Mertz (Ed.), Trace Elements in Human and Animal Nutrition (5th ed., pp. 1-137). Academic Press, Inc., New York, USA. https://doi.org/10.1016/ B978-0-08-092469-4.50005-4

Haug, H., Christophersen, O. A., Kinabo, J., Kaunda, W., \& Eik, L. O. (2010). Use of dried kapenta (Limnothrissa miuodon and Stolothrissa tanganicae) and other products based on whole fish for complementing maize-based diets. African Journal of Food Nutritional Development, 10, 2478-2478. https://doi.org/10.4314/ajfand.v10i5.56330

Hseu, Z. Y. (2006). Extractability and bioavailability of zinc overtime in three tropical soils incubated with biosolids. Chemosphere, 63, 762-771. https://doi.org/10.1016/j.chemosphere.2005.08.014

Iyengar, S. S., Martens, D. C., \& Miller, W. P. (1981). Distribution and plant availability of soil zinc fractions. Soil Science Society of America Journal, 45, 735-739. https://doi.org/10.2136/sssaj1981.036159950045 $00040012 \mathrm{x}$

Johnson, C. E., \& Petras, R. J. (1998). Distribution of zinc and lead fractions within a forest spodosol. Soil Science Society America Journal, 62, 782-789. https://doi.org/10.2136/sssaj1998.03615995006200030035x

Joshi, D., Srivastava, P. C., Dwivedi, R., \& Pachauri, S. P. (2014). Chemical speciation of Zn in acidic soils: Suitable soil extractant for assessing Zn availability to maize (Zea mays L.). Chemical Speciation \& Bioavailability, 26(3), 148-157. https://doi.org/10.3184/095422914X14035354272035

Karak, T., Das, D. K., \& Debtanu, M. (2006). Yield and zinc uptake in rice (Oryza sativa) as influenced by sources and times of zinc application. Indian Journal of Agricultural Sciences, 76(6), 346-348.

Kiekens, L. (1995). Zinc. In B. J. Alloway (Ed.), Heavy Metals in Soils (pp. 284-303). Chapman and Hall, London. https://doi.org/10.1007/978-94-011-1344-1_13

Leleyter, L., \& Baraud, F. (2006). Selectivity and efficiency of the acidosolluble extraction in sequential extraction procedure. International Journal of Soil Science, 12, 168-170.

Lu, A., Zhang, S., \& Shan, X. (2004). Time effect on the fractionation of heavy metals in soils. Geoderma, 125(3), 225-234. 
Madyiwa, S., Chimbari, M., Nyamangara, J., \& Bangira, C. (2002). Cumulative effects of sewage sludge and effluent mixture application on soil properties of a sandy soil under a mixture of star and kikuyu in Zimbabwe. Physical and Chemical Earth, 27, 747-753. https://doi.org/10.1016/S1474-7065(02)00062-1

Maftoun, M., \& Karimian, N. (1989). Relative efficiency of two zinc sources for maize in two calcareous soils from arid area of Iran. Agronomie, 9, 771-775. https://doi.org/10.1051/agro:19890804

Mapiki, A., \& Phiri, S. (1995). Soil fertility constraints and management options in northern Zambia. Proc. national symposium proceedings: A system approach to long term soil productivity (pp. 11-29). Department of Soil Sciences, University of Zambia.

Margui, E., Queralt, I., Carvelho, M. L., \& Hidalgo, M. V. (2007). Assessment of metal ability to vegetation (Betula pendula) in pb-zn ore concentrate residues with different features. Environmental Pollution, 154, 179-184. https://doi.org/10.1016/j.envpol.2006.03.028

McDonald, G. K., Graham, R. D., Lloyd, J., Lewis, J., Lonergan, P., \& Khabas-Saberi, H. (2001). Breeding for zinc and manganese efficiency in wheat and barley. Australia Society of Agronomy.

Milivojevic, J., Jakovljevic, M., \& Jelic, M. (2005). Content of different forms of micronutrients in Smonitza soils in Serbia. Acta Biologica Lugoslavia, 54(2), 73-84.

Modaihsh, A. S. (1997). Foliar application of chelated and non-chelated metals for supplying micronutrients to wheat grown on calcareous soil. Expl. Agric., 33(2), 237-345. https://doi.org/10.1017/S001447979700001X

Obrador, A., Alvarez, J. M., Lopez-Valdivia, L. M., Gonzalez, D., Novillo, J., \& Rico, M. I. (2007). Relationships of soil properties with $\mathrm{Mn}$ and $\mathrm{Zn}$ distribution in acidic soils and their uptake by barley crop. Geoderma, 137, 432-443. https://doi.org/10.1016/j.geoderma.2006.10.001

Panel on Micronutrients. (2001). Dietary Reference Intakes for Vitamin A, Vitamin K, Arsenic, Boron, Chromium, Copper, Iodine, Iron, Manganese, Molybdenum, Nickel, Silicon, Vanadium and Zinc (pp. 442-501). National Academy, Washington DC, USA.

Ramos, L., Gonzalez, J. M., \& Hernandez, L. M. (1999). Sequential extraction of copper, lead, cadmium and zinc in sediments from Ebro Rivers (Spain): Relationship with levels determined in Earthworms. Bulletin of Environment Contamination Toxicol., 62, 301-308. https://doi.org/10.1007/s001289900874

Ramzan, S., Bhat, A. M., Kirmani, N. A., \& Rasool, R. (2014). Fraction of zinc and their association with soil properties in soils of Kashmir Himalayas. International Invention Journal of Agriculture and Soil Science, 2(8), 132-142.

Rieuwerts, J. S., Ashmore, M. R., Farago, M. E., \& Thornton, I. (2006). The influence of soil characteristics on the extractability of $\mathrm{Cd}, \mathrm{Pb}$ and $\mathrm{Zn}$ in upland and moorland soils. Science Total Environment, 366, 864-875. https://doi.org/10.1016/j.scitotenv.2005.08.023

Rieuwerts, J. S., Thornton, I., Farago, M. E., \& Ashmore, M. R. (1998). Factors influencing metal bioavailability in soils: preliminary investigations for the development of a critical loads approach for metals. Chem. Spec. Bioavail., 10, 61-75. https://doi.org/10.3184/095422998782775835

Saffari, M., Yasrebi, J., Karimian, N., \& Shan, X. Q. (2009). Evaluation of three sequential extraction methods for fractionation of zinc in calcareous and acidic soils. Residual Biology Science, 4, 848-857.

Shiowanata, J., Tantidanai, N., Nookabkaew, S., \& Nacapricha, D. (2001). A novel continuous flow sequential extraction procedure for metal speciation in solids. Journal of Environmental Quality, 30, 1195-1205. https://doi.org/10.2134/jeq2001.3041195x

Shuman, L. M. (1991). Chemical Forms of Micronutrients in Soils. In J. J. Mortvedt (Ed.), Micronutrients in Agriculture. SSSA, Madison, WI.

Sinha, M. K., Dhillon, K. S., Dhillon, S. K., \& Dyanaud, S. (1978). Solubility relationships of Mn, Fe, Cu and $\mathrm{Zn}$ in alkaline and calcareous soils. Australian Journal of Soil Research, 16(1), 19-20. https://doi.org/ 10.1071/SR9780019

Sparks, D. L. (1995). Kinetics of metal sorption reactions. In H. E. Allen, C. P. Huang, G. W. Bailey, \& A. R. Bowers (Eds.), Metal speciation and contamination of soil (pp. 35-58). Lewis Publishers, Chelsea, Michigan. 
Sposito, G., Lund, L. J., \& Chang, A. C. (1982). Trace metal chemistry in arid-zone field soils amended with sewage sludge: I. Fractionation of $\mathrm{Ni}, \mathrm{Cu}, \mathrm{Zn}, \mathrm{Cd}$ and $\mathrm{Pb}$ in solid phases. Soil Science Society of American Journal, 46, 260-264. https://doi.org/10.2136/sssaj1982.03615995004600020009x

Tehrain, M. M. (2005). Zinc mobility and its distribution among different pools in soil. Geophysical Research Abstracts, 7. Retrieved from http://www.cosis.net/abstracts/egu05/10561/egu05-j-10561.pdf

Tembo, B. D., Sichilongo, K., \& Cernak, J. (2006). Distribution of Copper, Lead, Cadmium and Zinc concentrations in soils around Kabwe town in Zambia. Chemosphere, 63, 497-501. https://doi.org/10.1016/ j.chemosphere.2005.08.002

Udo, E. J., \& Ogunwale, J. A. (1986). Laboratory manual for analysis of soil, plant and water samples (2nd ed., p. 174).

Udom, B. E., Mbagwu, J. S. C., Adesodun, J. K., \& Agbin, N. N. (2004). Distribution of Zn, Cd, Cu and Pb in a tropical Ultisol after long term disposal of sewage sludge. Environment International, 30, 467-470. https://doi.org/10.1016/j.envint.2003.09.004

Zauyah, S., Juliana, B., Noorhafizah, R., Fauziah, C. I., \& Rosenani, A. B. (2004). Concentration and Speciation of Heavy Metals in Some Cultivated and Uncultivated Ultisols and Inceptisols in Peninsular Malaysia [CDROM]. A paper presented at the 3rd Australian New Zealand Soils Conference, December 5-9, 2004, University of Sydney, Australia. Retrieved from http://www.regional.org.au/au/asssi

Zerbe, J., Sobczynski, T., Elbanowska, H., \& Siepak, J. (1999). Speciation of heavy metals in bottom sediments of lakes. Journal of Environmental Studies, 8, 331-339.

\section{Copyrights}

Copyright for this article is retained by the author(s), with first publication rights granted to the journal.

This is an open-access article distributed under the terms and conditions of the Creative Commons Attribution license (http://creativecommons.org/licenses/by/4.0/). 